\title{
Deep incarnation: From deep history to post-axial religion
}

\begin{abstract}
Author:
Niels Henrik Gregersen ${ }^{1,2}$

Affiliations:

${ }^{1}$ Section for Systematic

Theology, Faculty of

Theology, University of

Copenhagen, Denmark

2Department of Dogmatics and Christian Ethics, Faculty of Theology, University of Pretoria

Project leader: D.P. Veldsman Project number: 01224719

\section{Description}

Prof. Dr Niels Henrik Gregersen is part of the research project, 'Religious Experience from an evolutionary perspective', directed by Prof. Dr Danie Veldsman, Department Dogmatics and Christian Ethics, Faculty of Theology, University of Pretoria.
\end{abstract}

\section{Corresponding author:} Niels Henrik Gregersen, nhg@teol.ku.dk

Dates:

Received: 11 Apr. 2016

Accepted: 14 June 2016

Published: 28 Oct. 2016

How to cite this article: Gregersen, N.H., 2016, 'Deep incarnation: From deep history to post-axial religion', HTS Teologiese Studies/ Theological Studies 72(4), a3428. http://dx.doi. org/10.4102/hts.v72i4.3428

\section{Copyright:}

(c) 2016. The Authors. Licensee: AOSIS. This work is licensed under the Creative Commons Attribution License.

Read online:

Scan this QR
code with your
smart phone or
mobile device
to read online.

This article presents in broad outline the theological concept of deep incarnation and brings it into dialogue with correlative ideas of deep history and deep sociality. It will be argued that neither Christology, nor evolution, can be properly understood from a chronocentric perspective. Evolution is not only about development but also about the exploration of ecospace. Likewise, a contemporary Christology should explicate incarnation as a divine assumption of the full ecospace of the material world of creation. It will then be argued that an interactionist view of deep history is preferable to the evolutionary cognitive theory of religion (ECTR). Against this background, the paper will explore Jesus of Nazareth's role in the context of post-axial mentalities.

\section{Introduction}

In addressing the South African Science and Religion Forum on the topic of deep incarnation and deep history, I do so with a profound awareness that we are situated here amongst the birth seeds of humanity. ${ }^{1}$ The fields and caves around us contain the 'Cradle of Humankind', within which around $40 \%$ of all hominid fossils have been excavated (most recently Homo naledi). In this place, we are in contact with deep history. Yet we also find in South Africa a 'microcosm of the world' (Augustine Shutte), a melting pot for many striving influences and ways of life. In this country, words like 'conflict' and 'reconciliation' have gained a special meaning. Coming from the more homogenous country of Denmark, just as much as I am here to present to you, I am also here, therefore, as a learner too. Indeed, in the past I have learned much from South African social thinkers, and from the significant pool of scholars within the field of science and religion that South Africa has produced - some coming from physics, others from philosophy and theology (cf. Conradie \& Du Toit 2015:455-479). ${ }^{2}$

\section{Why deep incarnation}

My task today is to develop further the concept of deep incarnation whose first contours I laid out in a 2001 article, 'The Cross of Christ in an Evolutionary World'. In that paper, I argued that a radical or 'deep' view of incarnation implies 'an incarnation into the very tissue of biological existence, and system of nature'. The focus was here on the cross of Christ as a divine selfidentification with the frailty and pain of biological creatures: 'God assumed not only the body of a particular human person: Jesus from Nazareth. God also assumed a humanity and a vital and fragile body susceptible to decay and death'. My task today is to develop further the concept of deep incarnation that I laid out in its first contours in a 2001 article, 'The Cross of Christ in an Evolutionary World'. I here argued that a radical or deep view of incarnation implies 'an incarnation into the very tissue of biological existence, and system of nature'. The focus was here on the cross of Christ as a divine self-identification with the frailty and pain of biological creatures:

God assumed not only the body of a particular human person: Jesus from Nazareth. God also assumed a human being and a vital and fragile body susceptible to decay and death. (Gregersen 2001:204-205)

In this context, I coined the term 'deep incarnation' almost in passing, as part of a theological response to the problem of evolutionary suffering. In the light of evolution, suffering amongst 1.Paper given for South African Science and Religion Forum (SASRF) Conference on 'Creation, Consciousness and Christology: Evolutionary
Perspectives', University of Pretoria, September 16, 2015. The author wishes to express his gratitude to Dr. Harris Wiseman for language improvements.

2.Allow me to note with gratitude that I have much benefitted from the hospitality of South African colleagues and friends, both in Princeton through Wentzel and Hester van Huyssteen during the 1990's, and later in 1999 via the 1999 SASFR conference in Pretoria (Cornel du Toit and Daniel Veldsman), Durban (Peter Barrett and friends), and Cape Town (George Ellis) (cf. Du Toit 2000).

Note: Original Research: Volume 17 in the South African Science and Religion Forum Series, edited by Prof. Cornel du Toit (UNISA) and Prof. Daniel Veldsman, entitled 'Creation, Consciousness and Christology: Evolutionary Perspectives', Proceedings of the 20th conference of the South African Science and Religion Forum (SASRF) of the Research Institute for Theology and Religion held at the University of South Africa, Pretoria 16-18 September 2015. 
sentient beings is not only an accidental by-product of evolution, but is part and parcel of the evolution itself, driven as it is by natural selection. Creation and evolution makes up a package deal, as it were, in which woes and joys are inextricably conjoined. Hence, we would not have the protective atmosphere of our Earth without volcanos; we would not have seen the proliferation of life without the cracks of the tectonic plates responsible for earthquakes and tsunamis; we would not have the alertness and sudden movements of animals without the interplay between pray and predators. All this goes, for good and bad, also for human life. As pointedly expressed by the UNISA professor, Ramathate Dolamo, in an early discussion of deep incarnation: 'Whenever we celebrate something, we slaughter something' (R. Dolamo [LWF global conference on theology in the life of the Lutheran churches] pers. comm., 2009).

So, how could the idea that 'God became human' in a man called Jesus, living in a remote area of Palestine 2000 years ago, possibly come to offer any relevant perspective to problems of suffering and decay during these first 4 billion years of biological life, leading to sentient beings perhaps 600 million years ago, and to the formation of animal group life and human civilisation some million years ago? Isn't there something unconvincing, anachronistic even, about bringing Jesus into the much larger canvass of evolution?

Perhaps so, as long as one assumes a modern individualised concept of what it means to be a human. If we think of the incarnation in purely historical terms (Jesus as a bygone historical figure), and at the same time subscribe to the metaphysics of historicism (all that exists only exists as indexed in time and space), we could only speak of a skindeep incarnation. Our concepts of incarnation would then be framed within a dermal metaphysics, presupposing that human beings are what they are only within the skin of their bodies, just like their moods and thoughts exist entirely within their skulls.

In contrast, deep incarnation presupposes a wide-scope view of incarnation by focusing on the extended mind of Jesus, constituted by the landscapes in which he is placed, the birds in the sky, the lilies in the field, and many human groups and fractions that he - like us today - meet along our ways (Gregersen 2012:235-245). The very notion of incarnation is to be expressed as part of an extensive interactionist view of the embodied mind. But the concept of incarnation also operates within the horizon of a cosmic Christology. In the Pauline and Johannine traditions Christology is part of both a creation theology, and a cosmic Wisdom Christology too.

Admittedly it took me some years to become aware of the wider implications of the concept of deep incarnation. I came to realise that the idea of deep incarnation contains a critique of prevailing Western theological traditions, both regarding their anthropocentrism and chronocentrism.
In the Middle Ages, Anselm of Canterbury posed the question, Cur deus homo - Why did God become human? But nowhere in the New Testament does one find the view expressed that God simply became man. Firstly, it is neither God the Father nor the Spirit but only the Son of God that is coming into the world of flesh - not only in flesh, but as flesh (Gregersen 2013a:251-262). Secondly, it is the concept of flesh (in Greek, sarx), and not that of humanity that is highlighted in the Prologue of John: 'And the Word became flesh and lived among us' (Jn 1:14). Similarly Paul said that God 'sent his own Son in the likeness of sinful flesh' (Rm 8:3). Also in the Philippian hymn of the self-emptying of Christ, the humanity of Christ is not depicted as the apex of creation but as the most pitiful creature: Christ Jesus:

emptied himself, taking the form of a slave, being born in human likeness; and being found in human form, he humbled himself, and became obedient to the point of death - even death on a cross. (Phil 2:7-8)

The Johannine expression that the divine Logos becomes flesh connotes an understanding of the divine embodied in a frail materiality, and in a world of sins (in the case of humans). The Greek term sarx thus means, (1) the concrete body of Jesus, (2) the human world of sin and (3) the whole wool and wharf of materiality - everything material, from cosmic dust to mud, to the life-forms of grass and weed onwards to animal and human existence. Accordingly the theological concept of incarnation has to be extended into the whole fabric of physical and biological creation.

Moreover, in Jesus God assumes not only the sunny side of reality but also the darker, chaotic aspects of reality:

Deep incarnation is the view that God's own Logos (Wisdom and Word) was made flesh in Jesus the Christ in such a comprehensive manner that God, by assuming the particular life story of Jesus the Jew from Nazareth, also conjoined the material conditions of creaturely existence ('all flesh'), shared and ennobled the fate of all biological life forms ('grass' and 'lilies'), and experienced the pains of sensitive creatures ('sparrows' and 'foxes') from within. Deep incarnation thus presupposes a radical embodiment that reaches into in the roots (radices) of material and biological existence as well as into the darker sides of creation: the tenebrae creationis. (Gregersen 2015a:225-226)

In this view, God does not only tolerate material existence, but God becomes involved with the world, appears within it, shares creaturely experiences from within, and - if we follow the particular trajectory of the Jesus story - takes side with the victims of evolution and social injustice. Jesus the Immanuel ('the God with us') died the death of an animal, and he died as a social outcast, his death being the result of a miscarriage of justice by religious authorities as well as political powers, and in the end scorned even by ordinary people. If God's own being was present in the life story of Jesus, as Christians believe, then Christ is present from the bottom of the universe and up, emerging from within the realm of creation no less than descending from above. The proposal of deep incarnation is thus both 'high' in Christology and 'low' in materiality. 


\section{Moving beyond anthropocentrism while accepting anthropogenic conditions}

From the perspective of deep incarnation, the general gist of Western theology appears to be overly anthropocentric, focusing particularly on human individuality. It is understandable that the Christian tradition has given priority to humanity when speaking of salvation. The creatures in need of salvation are, obviously, creatures such as ourselves, while conversions are hardly needed for grass, sparrows and dolphins. That being so, as emphasised by Joseph Sittler, Ein Mensch ist kein Mensch: solitary individuals are not real human beings (Smith 2015:69). A similar view is encapsulated in the principle of the South African philosophy of Ubuntu which speaks of a universal bond of sharing that connects all humanity. A person is a person through other persons: Umuntu ngumuntu ngabantu (Forster 2007:245-289).

The crucial question, then, must be whether our sense of interdependence should be directed only towards those within our own group, those with whom we have ties of obligations (the family, the clan, the peer group, the patron), and so on - a narrow form of communitarianism? Or, does this interhuman codependence reach beyond our own communities - to those who do not look like us, do not think like us, and do not believe as we believe? Is there, in the midst of our many differences, often profound differences, also something like a basic shared humanity? It is beyond doubt that the Jesus tradition underlying and sustaining the concept of deep incarnation speaks consistently about a shared sense of humaneness, transcending the divide between friends and foes, as exemplified in Jesus' parable of the good Samaritan (Lk 10:25-37).

Yet concepts of personhood, whatever their provenance, also need to respond to another question. Do our concepts of an interhuman community also include non-human agents such as animals and the landscapes into which human lives are woven, and upon which we are most certainly dependent. Certainly, more recent attempts to reformulate a philosophy of Ubuntu emphasise this sort of question. As A.O. Balcomb put it, "The interconnectedness of the universe, beginning with the creator and going all the way down to rocks, can surely not be more strongly stated [than in the Ubuntu philosophy]. Here is a system that is indeed a Cartesian nightmare and a Whiteheadian dream' (Balcomb 2004:71). If this is so, the theological proposal of deep incarnation would find a most congenial and vivid correlate in the mindset of Ubuntu philosophy.

But there is more, for we need to pose a third follow-up question: what do all these considerations mean for human persons endowed with a consciousness. Such consciousness is always individualised in the very basic sense that each of us have to respond precisely as persons to the environmental and communal contexts of which we are part. I shall return to this question towards the end of the paper when discussing the questions of post-axial religion. For the moment it will suffice to outline a distinction between anthropocentric and anthropogenic frames of reference. The suggestion will be made that an anthropocentric understanding of humanity and the world is problematic. Nonetheless, we have to take seriously the fact that human feelings, perceptions, and concepts will always be our inevitable point of departure. What this entails, however, is that all human thinking is unavoidably anthropogenic, that is, always starting out from a human point of view. The inevitability of human point of departure does not necessitate an anthropocentric view, which presupposes that the meaning of life is only about its value for human beings. Much joy and suffering alike take place in this universe fully beyond its human recognition. Indeed, such goings on outstrip our capacity to even imagine them. The concept of the Logos, or Wisdom of God, here serves as a constraining concept, pointing to the limitations of human wisdom.

\section{Moving beyond chronocentrism: The relevance of place and ecospace}

I would like to point to another problem that the concept of deep incarnation raises for our dominant Western theological paradigms. Here, I am thinking of the overprivileging of time over space. As the British crime writer and lay theologian Dorothy Sayers put it, the Christian dogma of incarnation is unique in its claim that God has not only created the framework of the world, but also has a 'date' within it, in the twofold sense of both representing a location in time, but also in the sense of an appointment set with somebody (cf. Gregersen 2010:167-182; Sayers 1969:14). ${ }^{3}$

Indeed, that God has a 'date' with human beings is the particular point of Christian faith. It is therefore understandable that there has been a certain privileging of time within the Christian tradition. Some have given priority to history in terms of God's oikonomia of salvation (in both Eastern and Western theology); some have pointed to crucial temporal events or moments (as in Paul Tillich's kairos theology, and in the South African Kairos-Document); some in terms of the universalhistory of humanity (Universalgeschichte), as in the theology of Wolfhart Pannenberg.

The problem with such focus on time and human history, however, has been the corresponding neglect of space. By forgetting place and body, Christian self-reflection unnecessarily loses some significant scope and becomes chronocentric in its theologising. Even though Christians routinely speak of incarnation (incarnation literally means 'going into flesh'), many theologians have been preoccupied with the idea of 'God coming to mind' (to use a phrase of Levinas). But paradoxically, by elevating ourselves above space and place we are dwarfing ourselves. By claiming to possess humanity as an autonomous domain, there is a sense in which we become less than human, because our humanity is inextricably tied up in that web of creation and needs to be understood in light of that web.

3.In this section, I adapt arguments from my essay, 'Deep incarnation: Logos became flesh' (Gregersen 2010). 
Likewise, we are dwarfing the potentials of Christology for broaching wider questions of philosophy, science and religion, if we think that Christology can be explicated solely within a historicist framework, such that that the ultimate task of theology regarding the person of Jesus involves only reconstructing him as a remarkable individual of a bygone past. But speaking of Jesus as Christ means that God was in Jesus the Christ-in such a penetrating way that this transverses all of space and time. Put differently, the words and deeds of Jesus as Christ manifest who God was, is and will be forever and this includes the full scope of the billions of years before and after the Jesus story. As within the sciences, we here have to reflect on repetitive features and perennial issues that are always exemplified ('instantiated') in time and space, but which extend beyond any given single time or space unit. This goes for God the creator, God the eternal Son, and the Holy Spirit, just as it does for quantum fields and laws of gravity.

As such, I am bringing to the table a rather specific theological proposal for science and religion discussion. The view of deep incarnation speaks of a universe in which God is not only present in a general manner (as expressed in traditional concepts of the immanent activity of the divine creator), but in which God is conjoining and uniting with the material world in the bodily form of God's incarnate Son of Logos or Wisdom. Hence God is feeling and experiencing material existence from the inside out, while sharing the joys and sufferings of God's own creatures. Accordingly, what from our temporalised perspective is an event that took place in the 30 years of the life story of Jesus is from the perspective of eternity a process beginning with creation itself, which culminated in the incarnation of Jesus, and is still with us because of the depths of the resurrection of Christ.

The Roman-Catholic feminist Elizabeth Johnson (2015: 133-156) has helpfully coined the term 'deep resurrection' as a correlate to deep incarnation. For, not only does the particular incarnation in Jesus of Nazareth go the whole way down, from the particulars of his human personhood into the depths of biological and physical materiality, but the biblical concept of incarnation also states that the fullness of divine identity was present in him - he was fully divine in the midst of material existence. ${ }^{4}$ Accordingly, the historical incarnation goes deep into the heart of divine life, at once expressing the depths of God's fatherly love for the world, ${ }^{5}$ while also bringing into divine life the inside experience of the world of creation, so that in the end creatures will live and become united in the eternal life of God. ${ }^{6}$

In sum, there is no way of speaking about time without also speaking about space and place. Moreover, there is no way of speaking about time without also speaking of eternity in the sense of the copresence of all times (past and present).

4.Cf. Col 2:9: 'For in him the whole fullness (pleroma) of deity dwells bodily'

5.Cf. John 3:16: 'For God so loved the world that he gave his only son'.

6.John 17:22-23: 'so that they may be one, as we are one. I in them and you in me, that they may become completely one, so that the world may know that you have sent $\mathrm{me}$ and have loved them even as you have loved me'.

\section{A methodological interlude}

Here I will pose a few methodological reflections on the relations between theology and the natural sciences. The view of deep incarnation, as laid out above, cannot be translated into the worldview of empirical science, obviously. But this does not mean that there is no connection between the proposal of deep incarnation and scientific descriptions of reality. Here, I am in agreement with Wentzel van Huyssteen's view that there are many legitimate resources and forms of rationality over and above that specific form we find exemplified in the empirical sciences. As such, theology should not take it as necessary that it be subsumed under that specific scientific form of rationality, nor that it need find its place within existing sciences, be that quantum theory, evolutionary theory or information theory, and so on. Rather, theology should seek interdisciplinarity by bringing its own theories to the wider market of ideas and candidates for truth. As van Huyssteen put it: 'we should as theologians be able to enter the pluralist, multidisciplinary conversation with our full personal convictions intact and at the same time be empowered to step beyond the limitations of our contexts and traditions in critical self-reflection' (Gregersen 2015b: 141-159; Van Huyssteen 2011:78-79).

In my own work, I have perhaps focused less on such personal convictions than on the community-based traditions that have cultivated modes of thought hospitable to religious experiences. What are religious assumptions about? How are they backed up by underlying religious commitments? How can they be explicated in ways that are intelligible to partners outside of one's own discipline, and to people with only little religious sentiment? Working as a theologian in a secular context, I have argued that it is one of theology's tasks to redescribe, as far as possible, theological concerns in a language resonant with other forms of human inquiry. Here, the precept and exhortation is, as stated by Daniel Veldsman (2004:290): 'Connect!'7 However, the danger for the programme of the sort of contextual coherence theory that I have advocated (cf. Gregersen 1998:181-231) is that the theologian only tends to pick up views that are already friendly to his or her own perspective, while neglecting other relevant discussion partners. The danger is what Mikael Stenmark at Uppsala University has called a 'customised science', that is, a science tailored to conform to one's own prior commitments. ${ }^{8}$ My aim is to avoid this pitfall by giving due weight to well established aspects of science, and to discuss alternative scientific proposals that might be relevant to the idea of deep incarnation.

But there is also a danger going in the other direction: sliding from science into theology by theologising scientific concepts.

7.In this article Veldsman $(2004: 292-295)$ is also raising the critical question whether the role of religious experience is not underestimated in standard science-andthe role of religious experience is not underestimated in standard science-andreligion discussions. This is in my view a valid concern. Certainly, cognitive aspects of religion are always undergirded by long-standing emotions and moods. While the interactionist view of religion in ecospace might be a step in the right direction, it is
hardly sufficient in itself. 8.See http://www.crs.uu.se/Research/impactofreligion/Theme_6/customized science, viewed 15 March 2016 
For example, in public and academic contexts, scholars in science and religion are regularly asked the question: 'What are the "implications" of evolutionary theory for theology?" But there is, in my view, reason for caution when speaking too straightforwardly about 'implications' of scientific theories for philosophy and theology. The question itself, even if asked in a friendly manner, suggests a one-way street leading from science to religion. But there exist no strict entailment relations between, say, evolutionary theory and concepts of divinity.

Firstly, unlike the physical sciences, the biological sciences are not fundamental sciences aiming at digging down into ultimate reality. Rather, the biological sciences belong to the category of the domain-specific sciences, concerned with explaining resilient structures and formative developments of living organisms, once life has emerged on planet Earth (and on other sites for life, if they exist). But because concepts of God are intrinsically related to the question of ultimate reality, the biological sciences cannot logically be their ultimate arbiter, even though evolutionary theory, as we shall see, is without question connected to religious self-reflection in many significant ways.

Secondly, concepts of God build on a vast repertoire of religious experiences, linguistic traditions and theological reflections, which seem to escape objective empirical modes of grasping at phenomena. Religious approaches to reality doubt and certainty, fear and trembling, longing and desire, and intimations of horizons of what is ultimately real - are not easily transported into data amenable for a subsequent empirical classification. In standard working patterns of the natural sciences, questions of personal meaning, value and significance, so pertinent for religious practitioners, are all excluded from scientific inquiry. After all, usually the sciences exercise a methodological puritanism with respect to the manifold world of phenomena (there are exceptions, fields such as ecology and the medical sciences). As we will see below, this does not mean that all aspects of religious experience necessarily fall beyond the scope of evolutionary explanation. To this end, discussion now moves to two contrasting paradigms: Evolutionary Cognitive Theory of Evolution and Deep History.

\section{Evolutionary cognitive theory of religion: Strengths and weaknesses}

The research literature on evolutionary cognitive theory of religion (ECTR) has been growing over the last 20 years, and we are now witnessing philosophically informed discussions on the results and limitations of the different proposals within this movement (Gregersen 2003; Visala 2011; cf. Watts \& Turner 2014). These ECTR studies exemplify, most likely, the first sustained attempt at a genuinely scientific theory of (some) religious representations and (some) ritual

9.For example, I was asked by Richard Bright (editor of the Interalia Magazine) about the religious 'implications' of the new scientific perspectives on complex systems, the religious 'mplications' of the new scientific perspectives on complex systen emergence, and information (c. Richard Bright \& Niels Henrik Gregersen, 2014, 'Complexity and theological perspectives', Interalia Magazine 1(4), 1-8, viewe 4 August 2014, from http://www.interaliamag.org/author/nielshenrikgregersen. practices. Even if there is no particular view of God entailed by evolutionary theory as such, it is suggested that biological frameworks may still be able to explain particular aspects of the cultural persistence of religious mentalities and practices.

ECTR is potentially of significance for understanding the formation of concepts of gods and other so-called 'supernatural agents' over time and across cultures. The Darwinian framework of these studies is clear, insofar as ECTR builds on the assumptions of evolutionary psychology. Although it has not been possible to identify genes for religion, evolutionary psychology and ECTR propose an intermediary step between genes and culture: genes are responsible for the hardwired modular structure of the brain, which then gives rise to, and puts constraints on, the repertoires of religious representations and ritual behaviours. The brain's modularity is thus hypothesised to be basically self-identical over 100000 years, or more. Fear of God and other supernatural agents, or human longing for partnering with such 'supernatural agents', are thus hypothesised to be derived from our built-in module for an 'agency detection device' (ADD). Although agency detection has been helpful in singling out potential predators (and helpers) in human prehistory, it has - so ECTR - been overdeveloped religiously into a more free-floating imagination of supernatural agents. Religious representation comes about in spontaneous moves from ADD to HADD ('hyperactive agency detection device'). So the basic theory goes.

In that way, ECTR claims to have explained why aspects of traditional theism (including invisible personal beings of several sorts, from ancestors to ghosts) are widespread across cultures, just as we have notions of divine ubiquity and everlastingness in just about any human culture. Folk religion involves an 'intuitive theism' or an 'intuitive spiritism', often in combination. We are naturally biased, so to speak, in favour of religious representations, because contingent experiences of certain sorts tend to trigger concepts of gods or spirits, produced by the HADD.

In particular, ECTR has been able to illuminate the tension between folk religion and the official theology of particular religious traditions. Buddhism, for example, officially claims that there exist no personalised souls and no personal gods; but in folk Buddhism ghosts and helper avatars are infinitely many. Likewise Christianity, most of whose denominations officially hold a Trinitarian faith, is often in folk Christianity transformed into a more generalised monotheism, often mediated by guardian angels, or saints (Barrett 2012:3-23).

ECTR takes statistical analysis as its evidence base. However, given the statistical nature of evolutionary explanations, ECTR does not have much to say about the particular trajectories of religious traditions as regards to religious languages and interpretations, rituals and habits. The same goes for reflexive forms of religion, such as that which philosophers and theologians over the ages have proposed about religion, or about God. After all, natural selection is 
unconcerned about truth and truth claims. Accordingly, a selection theory applied to culture may help explain to us what works fluently and is transmitted with ease, but it will have nothing to say about questions of truth, or coherence of ideas. Also, ECTR has nothing to say about the specific trajectories of religious tradition, for example, why the rather complex semantics of the Lord's Prayer continue to be practiced within Christianity, alongside even more complex practices such as the Eucharist. In similar ways, scientific theories and practices are highly 'unnatural', because it is only through the difficult procedures of theory-making and contrived experiments that science has prevailed in modern human history. So, in parallel to the distinction in naturalness between folk and theological reflection, much the same might be posited about certain scientific ideas too. For example, Isaac Newton's concept of matter as built up by corpuscular particles may be much more easily transmitted than something like quantum field theory, which is, needless to say, a highly complex affair, only accessible to a very small portion of the world's inhabitants.

Having raised these caveats, one can say that philosophers and theologians might learn from ECTR that the more contrived are our formulations of philosophical and theological views, the more unlikely we will be successful in terms of public dissemination. In order to serve as a public philosophy and theology, more reflexive forms of religious reflection need some means of being translatable back into the more natural domains of knowledge that are more readily grasped by the broader cognitive structures of the human mind. Experiential recognition is important for any philosopher of religion who wants to be heard and understood.

Evolutionary cognitive science may thus help explain the cultural believability of at least some features of classical theism. Also the spatial metaphors activated in the idea of panentheism are relatively easy to communicate and transmit. The container-metaphor of something small 'in' something bigger belongs to the 'metaphors we live by' (to use the term of Lakoff and Johnson). Accordingly, we have persistent religious intuitions of a belonging to, and of being embraced by divinity. ${ }^{10}$ ECTR also shows how some concepts of God simply do not feature in religious thought. For example, no theism harbours the idea that God is only active some days, say Sundays, and not also on Thursdays, or that God is confined to some designated places only. By comparison, the presence of God is often thought to be revealed, or experientially present, 'for us' only at some particular places or situations, without being universally available for human cognition.

What should we think about the widespread assumption of an invisible, omnipresent and all-knowing God across religious traditions? Again, it should be noted that there is no one-way street from ECTR to the evaluation of the status of

10.To my best knowledge (having asked colleagues working in the field), no ECTR program has as yet investigated the naturalness and statistical spread of panentheistic concepts of the divine. concepts of God. One too-prevalent interpretation of ECTR is to take it as the ultimate explanation of religious cognition, hence as a reduction of religious representations to innate anthropomorphic projections - projections into the skies, as it were. Such a reductive projection hypothesis is widespread in the academic milieu of ECTR proponents (Bering 2011; Boyer 2002). There are several problems with this view.

Firstly, we have what has been termed the problem of collateral damage. Because all our natural concepts are hypothetically derived from the hardware of our Stone Age brains, the same projection hypothesis would apply to all other products of our brain - our primary sense qualities, our concepts of causality, all our attributions of personhood, etc. (Barrett 2007:61-62). In this respect, our 'ordinary' ADD and 'extraordinary' propensities of HADD should be seen as placed on a continuum of more or less, rather than as belonging to two very different categories. ${ }^{11}$ Indeed, from this perspective, the bifurcation between 'natural' agents and 'supernatural' agents is far more problematic than acknowledged by ECTR proponents.

Secondly, one might well argue that the only evidence for the spread of theistic representations is the empirical evidence of theistic representations themselves, as expressed in a variety of psychological experiments, or in historical material. Evolutionary explanations do not by themselves have something extra to offer, apart from the assumption of macroevolutionary lineages of representation, of which we have only a very scant empirical record. Empirically speaking, ECTR rests on a good handful of evidence within psychological ECTR-experiments - with or without the added evolutionary hypotheses. ${ }^{12}$

Thirdly, even if the evolutionary explanation of psychological states were somehow correct, we would still have the problem of how to explain the hypothesised macro-evolutionary trajectory of religious representations. Who takes the podium when it comes to offer the ultimate explanation of religious developments throughout evolution? ${ }^{13}$ Justin L. Barrett opens up for the following option:

Some Christians, including myself, offer [this] account: God created people with the capability to know and love him but with the free will. Consequently, our God-endowed nature leads us to believe, but human endeavors apart from God's design may result in disbelief ... God may have fine-tuned the cosmos to allow for life and for evolution and then orchestrated mutations and selection to produce the sort of organism we are evolution through 'supernatural selection'. (Barrett 2004:123)

11.I'm here reminded of C.S. Peirce's concept of 'synechism', the assumption that everything in time and space is continuous (cf. Peirce 1998:1-3)

12.Interestingly, one of Justin Barrett's latest books on cognitive science of religion, Cognitive Science, Religion, and Theology: From Human Minds to Divine Minds (Barrett 2011) does not at all discuss ECTR. He also points out that scientific theories can be interpreted from different perspectives: 'A scientific explanation of how human cognitive systems form beliefs in gods only "explains away" gods if you how human cognitive systems form beliefs in gods only "explains away" gods if you already believe they don't exist. For believers, such explanation just specify the means by which actual gods are perceived and understood (or misunderstood)'
(Barret 2011:150).

13.I'm aware that evolutionary theory itself has a concept of ultimate explanation (in terms of evolutionary net-effects) as opposed to proximate causes, but I refer here to ultimate explanation in a philosophical sense. 
Hermeneutically trained philosophers of religion will probably find this statement somewhat crude, and I admit to sharing some of the same concerns here. However, if one explores the language game of something explaining something else in a cause-effect way, then Barrett's argument is not as simplistic as it might seem. For as earlier stated, evolutionary science, as ordinarily understood, works by bracketing ultimate explanations (in the philosophical sense of the term). Accordingly, if one is seeking some manner of ultimate explanation, then some higher-order explanation must also be sought for evolutionary processes too, because evolutionary theory, again, is not able to deliver ultimate explanations about reality. So too with our naturalist assumptions - for it is physics and chemistry that explain biology, and not the other way around.

What can be learned from ECTR, in my view, is the amount of sheer repetition in cultural evolution, the patterns. If we take the feature of evolutionary recurrence seriously in our interpretations of reality, we might learn to see ourselves not only as having friends (such as bacteria and gene-elements) far back in evolutionary time, but also as having friends, colleagues and sojourners, amongst believers within other traditions than our own as well. After all, the cognitive apparatus of the human mind is limited to rather few thoughts and forms of religious life. Therefore, it should not come as too great a surprise that philosophical debates within one tradition can often be found to be present, in some broad form, in other religious traditions too.

What is missing from the theory structure of ECTR, curiously enough, is an understanding of religion as taking place in the interface between human beings and their natural and social environments. Evolution is about the exploration of ecospace by organisms, individuals and groups. Only a very limited NeoDarwinian theory can be based on a gene-centred individualism and a corresponding chronocentric view of genetic lineages. But given the general nature of their assumptions, evolutionary psychology and ECTR are interested in the genetics of individuals or human groups. Likewise with ECTR, we do not find any interest in the functional complexities that emerge in the interface between human groups and their environments. The HAAD hypothesis is supposed to carry the full burden of explaining religious representations and belief, as if nothing else is needed from an explanatory perspective, and as if nothing has happened between the Stone Age and our age in terms of religious development.

To sum up, there is something highly 'unbiological' about the core assumptions of evolutionary psychology and ECTR. Biologically speaking, there is no evolution taking place outside of contingent ecological settings. Again, evolution is about the exploration of ecospace. Thus, evolution concerns both time and place: evolutionary developments within one group lead to new challenges and spatial configurations to be explored by other species. It is simply not possible to study the evolution of functionally complex systems without discussing features such as niche construction, that is, the formation of concrete structures that are adaptive for organisms (Mühling 2014). ${ }^{14}$

\section{Deep history and the role of consciousness}

Now I wish to discuss the recent proposal of deep history as a corollary to the concept of deep incarnation and the question of hominisation. 'Deep history' is a proposal coming out of a collaboration between Harvard prehistorians Daniel Lord Smail and Andrew Shyrock, both of whom question the standard separation between history and prehistory. Shyrock and Smail remind us that also scientists are in need of metanarratives, and today the dominant meta-narrative is phrased in evolutionary terms. Yet unlike proponents of the ECTR program, Smail does take the lesson of 'interactionist approaches to genes and environment' when suggesting that 'many social skills and social pathologies have both genetic and environmental components' (cf. Gregersen 2013b: 278-279; Smail 2008:136).

Using the general insight that emergent systems may generate punctuations and non-linear trends at any scale of analysis, Smail and Shyrock propose a variety of alternative governing metaphors and theoretical perspectives. These include kinshipping, family trees, co-evolutionary webs and spirals, extensions of social relations, fractal repetitions of patterns going from deep time into human civilisations and scalar integrations (Shyrock \& Smail 2011:3-31). ${ }^{15}$ Not only do we share many of the same genes as our forebears, but quite a few of our basic cultural practices reveal a deep evolutionary presence in the midst of our civilisation. Numerous examples can be elaborated. One might think of the importance of energy exchanges with our environments: 'Ecological systems are the products of the organisms that inhabit them' (Shyrock \& Smail 2011:78). Or, one might think of the role of the body as a means of communication far below the threshold of intentional consciousness: 'Bodies also extend over space' (Shyrock \& Smail 2011:58). One might think about patterns of our sharing of food that are similar to that of birds and other mammals, or of new ritualised forms by relating food to domination: 'Food became a social differentiator' (Shyrock \& Smail 2011:151). Or reflect on the important role of 'deep kinshipping', for kinship is not only defined by genetic lines, but also by adoptions, household regulations and cultural affinities, including differentiations between male and female, incest taboos between brothers and sisters, rules for food sharing etc. In this way, kinshipping evolves as 'a gradual thickening of social kinship', but may even be widened to 'include relations among species and environments' (Shyrock \& Smail 2011:187). Think, for

14. Note that the centrality of niche-construction in evolution is uncontroversial within evolutionary biology. It is only debatable whether or not niche construction is an additional evolutionary mechanism in relation to standard neo-Darwinian the see the arguments pro and con in Scott-Phillips and Laland (2014:1231-1243).

15.Shyrock and Smail (2011:19) state, 'We propose a different array of governing metaphors. When skillfully deployed, analytical devices such as kinshipping, webs, metaphors. When skillfully deployed, analytical devices such as kinshipping, webs,
trees, fractals, spirals, extensions, and scalar integration can help us better trees, fractals, spirals, extensions, and scalar integration can help us better
comprehend the immensity of human time and the dynamic of connectedness that comprehend the immensity of human
both propels and constrains change'. 
example, of the domestication of dogs who became part of human households, or of the kinship relations established between groups and animals in totemism.

The deep historians, to the best of my knowledge, have not yet addressed the role of religion in ancient history. However, it only requires a little imagination to see the relevance of such deep time perspectives for a rereading of the gospels in light of such examples of 'prehistoric' traits in the Jesus story, to mention but one example. Here we also find a sense of the thickening of social relations centred around new definitions of kinship, proximity and strangeness: the 'brothers and sisters' of Jesus are those who do the will of God, our neighbour happens to be a Samaritan stranger, and his followers are even called to love their enemies. We have, on the one hand, culturally prevailing regulations and taboos concerning food sharing - yet, equally, we find Jesus transgressing the regulations about what food is allowed, when it is allowed, and with whom it is allowed, while also establishing new ways of communing.

From the perspective of deep history, evolution takes place in the continuous exchange between individual brain or minds and their social and natural environments. Even so, the importance of the social processes referred to above, are instantaneously understood by human beings, even by children in the schoolyard.

But it should also be noted that there is nothing deterministic about such biocultural processes, because they demand a constant reinterpretation and social negotiation. Semiautomatic reactions and self-aware interpretation here walk together in the creation of ecocultural nexuses. Something similar may be the case in the development of religious ideas, which are always, in one sense, spontaneous and easy to go with, yet in another sense always moulded in specific linguistic and cultural contexts. In this view, human minds are not to be understood as operating within closed modular boxes, so to speak, which then become activated by external triggers, but rather achieve a flow of awareness, from something almost instinctual to something far more evaluative, interpretative and potentially self-reflective.

Here we find ourselves thrown back to the question of consciousness. After all, embodied minds are not only situated in time and place, as tiny examples of the universe. Embodied minds are also those for whom salient aspects of ecospace are perceived, evaluated and responded to. This is the irreducible first-hand experience of embodied minds. How does this fit into the proposal of deep incarnation?

This question was raised to me by van Huyssteen in an earlier reply to several responses to his work, including deep incarnation. He puts his endorsement and his challenge as follows:

I would certainly agree that 'the incarnation of God's Word in Jesus Christ assumed the full gamut of material and biological existence through the specific humanity of Jesus'. However, I would like to suggest strongly that the full gamut of material and biological existence is not just assumed through the very specific humanity of Jesus, but first of all also for the very specific humanity of Jesus. In other words, before Gregersen makes the important move to 'deep ecology' and from there to 'deep incarnation', I would still like to know more about who this man Jesus was: how do we understand the person or 'self' of Jesus, as embedded in evolutionary history as we also are? And what would it mean to understand Jesus' embodied mind, his consciousness, the strengths and vulnerability of his male body, his own moral awareness and sexuality, his own symbolic propensities and religious imagination, and his self-awareness, as defining to the very core his own personhood? (Van Huyssteen 2011:80-81)

Van Huyssteen rightly points out that a convincing concept of deep incarnation should not only be stated in theological terms (from above, as it were), but must also go the bottomup way from the experience of Jesus. This is what I aimed to do in the article 'The Extensive Body of Jesus: The Social Body of Jesus According to Luke' (Gregersen 2012), written as the correlate to the more doctrinal article 'The Social Body of Christ: Three Dimensions of Deep Incarnation' (Gregersen 2015a). I agree that more work is needed. The problem is, however, that we cannot know what was going on in the mind of Jesus 2000 years ago. This is an established fact in historical Jesus-research, and we cannot hope to get around this fact. What we have to do (much like in body phenomenology) is to bracket the question of the individual consciousness of Jesus, and rather ask for the typical interactions of Jesus with his environments: the different landscapes (mountains, deserts, towns and cities) and the different groups that he is interacting with (people, elite groups, friends and foes).

Here I'm in basic agreement with van Huyssteen's emphasis, 'The embodied mind as such, therefore, includes the world beyond the membrane of the organism, especially the interpersonal world of self and other, which is also the world in which mind and brain are essentially formed' (Van Huyssteen 2011:82). I also find illuminative his reference to Thomas Fuchs' view that the brain 'acts as transformer, which translates the stimuli (single elements of a given situation) into wholes or Gestalt units, and finally into three cycles of embodiment: the affective self, the ecological self, and, ultimately, the intersubjective self' (Van Huyssteen 2011:82). In my own work, I have for the same reasons been particularly interested in the theory of the 'extended mind' by Andy Clark.

\section{Deep incarnation and post-axial religion}

As we have seen, human minds are extensive minds, always in transactions with their environments, while being selfreflective vis-à-vis the inherited cultures and religions. Likewise, the teachings and actions of Jesus must be understood as a highly self-reflexive form of religiosity. In the gospels he is sometimes depicted as speaking out in a humble attitude to the Jewish tradition (listening to the elders in the temple, Luke 4), sometimes in stark opposition to what was 
taught in tradition, even in the codified scriptures of the Hebrew Bible. In this sense, Jesus had a post-axial attitude towards his tradition.

As is well known, the term Achsenzeit comes from the existentialist philosopher Karl Jaspers. In Vom Ursprung und Ziel der Geschichte from 1949 he pointed to the deep cultural transformations taking place in the centuries around $500 \mathrm{BCE}$ in Greece, Israel, China and India. ${ }^{16}$ According to Jaspers, these axial transformations offer shared resources for humanity in an age of a potential atomic disaster. Proponents of the axial age hypothesis nonetheless define the 'axial' in slightly different terms. Some have seen its core feature in the depths of selfhood facilitated by the urbanisation and largescale empires of the axial age (so Jaspers). Others have foregrounded the basic tension between the transcendental and mundane orders and the emergence of intellectual elites questioning the established social powers (as suggested by the Jewish scholar Shmuel N. Eisenstadt). Others point to transformation towards rationalisation and the accompanying move towards universalised forms of ethics (so suggested by Jürgen Habermas in the vein of Max Weber).

Before his death in 2013, the sociologist Robert N. Bellah published a major work under the title, Religion in Human Evolution (abbreviated as RHE), followed by the discussion volume, The Axial Age and Its Consequences (abbreviated as AAC) (Bellah 2011; Bellah \& Joas 2012). The timeframe of Bellah's book spans from early hominisation to the axial age, and vigorously applied throughout is the contention that 'evolution is historical; history is evolutionary' (AAC 448). In describing his own view, Bellah writes that he is 'basically neo-Darwinian', aligning himself with the contention that variation and selection operate at the level of cultural traits and institutional structures (AAC 447). Bellah, however, argues for an organism-centred rather than a gene-centred view of evolution, and he points to the importance of niche constructions (think of beaver dams), which presuppose a goal-directedness of purposive organisms (RHE xii-xiii). Against this background, Bellah suggests that the reductive programs of evolutionary psychology (such as Pascal Boyer's) are 'particularly unhelpful', not least because of their 'lack of insight into religion as actually lived' (RHE 629) (Bellah 2012:260-270).

However, the tough mechanism of selection operates on religious life-forms too. Moreover, the evolutionary perspective implies that the mentalities of our forefathers and foremothers are still with us today. 'Nothing is ever lost', as Bellah puts it pointedly (RHE 267). But like other nicheconstructing animals, human beings are socially sheltered from some of the more harsh pressures of natural selection. In other words, not everything unfit, construed in the most brute sense, is removed by natural selection. Human cultures offer ample room for what Alison Gopnik has termed the 'useful uselessness' of play (RHE 89-90).

16.Some of the observations in this section are dealt with in more detail in Niels Henrik Gregersen, 'Religion and Axiality: Theological Reflections on Robert N. Bellah's Axial Age Hypothesis', forthcoming in Scottish Journal of Theology.
Along with science and art, religious activity exemplifies the human capacity to 'go offline', as we do when we fall asleep and dream, or when we play and use our uniquely human capacity for symbolic imagination (RHE 9). This capacity for play has evolutionary precursors in other mammalians, and even among birds. Bellah here refers to Gordon Burghardt's writings on the characteristics of animal play. Burghardt points to the following five features of play, (1) The limited survival value of play; (2) its inner pleasure, being enacted for its own sake; (3) its structural differentiation with temporal phases; (4) its modes of repetition; and finally (5) the 'relaxed field' of play sheltered from too strict pressures of selection (RHE 76-83).

Although play and ritual can be traced back in animal evolution, the capacity for symbolic transcendence may be a human prerogative, even though forms of expressive and indexical language exist also among higher animals. On this issue Bellah follows the argument of Terrence Deacon in the The Symbolic Species. Also, he is in line with Wentzel van Huyssteen who in his Gifford Lectures, Alone in the World?, suggested that institutional animal behaviour such as territoriality, ritualisation, play, and the unmistakable capacity for feelings of meaning and loss (death) may be seen as precursors of the human sense of sacred place and time, of ritual and myth, ecstasy and mysticism' (Van Huyssteen 2006:204).

One of the strongest attempts to characterise axial civilisations in general terms can be found in Shmuel N. Eisenstadt who refers to the 'combination of cultural orientations and institutional formations' (AAC 266) based in the rupture of social orders in the axial age. Axial visions include a broadening of horizons that opens up for universal perspectives, an ontological distinction between mundane and transcendental orders, and the normative subordination of the mundane under a transcending perspective (AAC 267). This characterisation has the advantage of seeing the axial age as emerging from historical constellations that facilitated a new cluster of attitudes towards society and the wider reality.

This cluster view of the axial age opens up for the possibility of recognising differences between the four principal axial civilisations. The concept of Tien (heaven) in China, for example, is not separated from mundane reality in the manner of the Jewish God, the Platonic realm of ideas, or the Buddhist concept of Nirvana.

Here, Bellah follows Merlin Donald's theory on the development from episodic cultures (also found among higher primates), to mimetic culture (in tribal societies), further on to mythic culture (in archaic society), towards the gradual formation of theoretical cultures, a development presupposing a new cognitive ability to store memory in external media outside the brain. In his earlier writings, Donald (2001) traced the beginnings of a theoretical culture back to about 40000 years ago. He pursues a longue durée perspective regarding the consequences of the axial age: 'The 
Axial Age might be considered the first period that germinated the seeds of later full-blown Theoretic cultures, such as those currently governing the developed world. The evolutionary trend in the direction of institutionalised analytic thinking grew very slowly' (AAC 70). For Donald as for Bellah, nothing is lost - the past of oral, ritualised and mythic cultures is present in the post-axial civilisations.

Thus, also the axial breakthroughs are 'the children of the archaic cultures from which they rose' (RHE 278). In this way, deep history is still with us. Religion, for example, is not only about ideas and representations but remains strongholds of religious commitment: 'Ritual, when thrown out at the front door, returns at the back door: there are even antiritual rituals. Our embodiment and its rhythms are inescapable' (RHE 278).

Judaism, Christianity and Islam exemplify the recurrent feature of a re-entry of rituality in scriptural religion. Studying the Torah (and the Talmud, etc.), studying the Qur' an (and the Hadith etc.) and studying the Bible (and the Church Fathers, etc.) becomes itself ritualised, when holy texts are canonised for use in the larger religious community. ${ }^{17}$ The dividing line only comes with respect to whether the scriptures are read and interpreted by scribes, priests or imams only, or whether they are also read by religious communities, consisting of ordinary people (who then take an active role in interpreting and responding to the holy texts during textual rituals). Here the homo ludens becomes a homo legens, and vice versa. There is no one thing without the other. ${ }^{18}$

Thus, it seems that continuities (not only breakthroughs) exist between the far religious past and the more general aspects of the axial age, and they do so by virtue of the external memory device of scriptures. Scriptural cultures, as emphasised by Merlin Donald, are not solely dependent on the 'engrams' of individual brains (as ECTR has it) but are stabilised as 'exograms', in cultural niche construction beyond the thoughts and experiences of individual, solitary minds.

If this is the case, note that there may be less of a common individualising move in the four axial traditions than is often suggested. When Jeremiah called for the Law to be written into the hearts of blood and flesh (Jer 31:33), this implied an interiorisation of the divine Law. But was a similar move present in Hinduism and Buddhism? The Buddha denied the reality of the individual soul as an illusion to be cast away. The Upanishads (perhaps here closer to Plato's correspondence between the soul and the world of ideas) refers to a long list of correspondences between the eye and the sun, the feet and the earth, the wind and the nostrils, and so on, which in the end are destined to be identical. The point here is that the core of the individual, the Atman, is identical with the Brahman, divinity itself. In brief, it is hard to find precursors for early modern ideas of individuality in the axial religions, especially in Eastern religions.

\section{This point is made by Line Søgaard Christensen (2015:15-35)}

18.I'm here taking up an expression from my Old Testament colleague at Aarhus University, Professor Hans J. Lundager Jensen.

\section{The cases of Japan and sub-Saharan Africa}

Shmuel Eisenstadt was himself aware of this fact. In his book, Japanese Civilization from 1996, he argued that a highly developed society such as Japan embraced most axial elements but remained fundamentally pre-axial regarding the divinity of the imperial system and the nationalistic values of a particular 'Japaneseness' (nihonjin). As we know from World War II, these archaic ideas had devastating consequences for the enemies of Japan, and in the end for Japan itself. Still today, Japanese politicians have difficulties to admit the brutality of their past (unlike, for example, a country like Germany).

The sociologist Ann Swidler (co-author with Bellah in their famous book Habits of the Heart) has made similar observations about the African situation, based primarily from her longterm fieldwork in Malawi. Her point is that 'Africans have embraced modernity with unparalleled enthusiasm' (AAC 223). In general, science and medicine are endorsed. Likewise there is according to Swidler a longing for 'official knowledge', as can be evidenced in credentials and diplomas (AAC 227). The longing for transcendence among most sub-Saharan Africans is one of the key markers of a post-axial mentality (AAC 237; cf. Du Toit 2010).

At the same time Swidler argues that 'African social patterns and the cultural codes that govern them have proved extraordinarily resilient' (AAC 235). In her view, important areas in African culture are not axialised. The first feature she mentions is syncretism, the fact that a spiritual universe is affirmed alongside affirmations of science and universalistic ideas of human rights. I would add that the same seems to apply to most societies in the Northern hemisphere too. Indeed, syncretism seems to be the rule rather than the exception, as rightly anticipated in ECTR and amply evidenced by empirical anthropological studies, also within Indian and North-European contexts (cf. Jørgensen 2008). ${ }^{19}$

The other point highlighted by Swidler is perhaps more widespread on the African continent than on the European continent. This concerns the fact that power structures of the client-serf type are part of tradition, and not often criticised openly and in principle. According to Swidler, 'Rulers are not directly held responsible to universalised, transcendent moralities, and capacities for collective action are still very much dependent on powers of chiefs and other traditional figures' (AAC 23).

I'm not able to judge on the generalisations that Swidler has raised. But in line with Bellah's generous view of the copresence of archaic and axial mindsets in religion, I wish to question the presupposition that axialisation is a one-way street leading away from archaic to modern mind-sets. There may well be many depressing aspects of archaic mentality around us, both in Africa and in other parts of the world, but,

19.On material based on Danish cancer-survivors, see Christine Tind JohannesenHenry, 'Polydox eschatology: Relating systematic and veryday theology in a cancer context', Studia Theologica 66(2), 107-129. 
equally, there will always be invigorating aspects of the interplay between axial and archaic aspects of culture too. In religion, rituals show a stronger resilience than theological schools of thought.

\section{A concluding perspective: The sapiential discourse of Jesus}

We may conclude, then, by asking as follows: exactly what is post-axial in our time? And what is post-axial about the teaching of Jesus? It seems to me that the foregrounding of 'theoretical cultures' in Donald Merlin's theory of axiality does not quite reach the level of axial universality that he is presupposing. We always live at deeper levels than we think. Nowhere do we find that theories are ruling the game of life, even though theories are important for channelling cultural preconceptions into a critical attitude. Indeed, we need to cast a critical eye towards tradition as much as to the alienating aspects of modernity, like the idea that human beings are solitary minds, living alone within their skulls with their thoughts. Here both biology and theology knows better.

The self-reflexivity of post-axial mentality should therefore not be limited to a theoretical attitude that looks at reality from a disengaged third-person perspective. Self-reflexivity may also be reached through a sapiential discourse, one which starts out from the middle of our involvements with shared experiences rather than attempting to take an elevated view from nowhere. Let me therefore end this paper with a reference to the sapiential forms of discourse that we find in the teachings of Jesus.

When Jesus wanted to exhort his followers to pray to God: 'knock, and the door will be opened for you', he did so by inviting his disciples to think about the following:

Is there anyone among you who, if your child asks for a fish, will give a snake instead of a fish? Or if the child asks for an egg, will give a scorpion? If you then, who are evil, know how to give good gifts to your children, how much more will the heavenly Father give the Holy Spirit to those who ask him! (Lk 11:12-13)

Jesus is backing up his encouragement to pray to God unreservedly by invoking common sense knowledge about what fathers tend to do. Although the theme and target of this saying is the practice of prayer, the thought experiment itself is based on an analogy to ordinary fathers. From here the inductive move from the minor to the major starts out. Assuming that even self-absorbed human parents want to help their children, 'how much more' will not the heavenly Father listen to human prayers? This argumentative move only works if the listeners or readers already share an intuition about what it means to be a father, while also presupposing some analogy between human fathers and the divine father. In order to reach its argumentative target, the thought experiment of Jesus is thus based on a wider set of assumptions, not included in the thought experiment itself, such as the receptiveness of the God, whom Jesus addresses as 'our heavenly Father' in the Lord's Prayer.
What is the kind of universality to which Jesus here appeals? Firstly, it is not something of a purely general nature. Gravity applies everywhere in the universe but caring fathers and mothers do not exist everywhere. That being so, wherever there is a father or mother who cares, something of universal significance emerges: the very phenomenon of caring itself. It is this phenomenon that serves as the common denominator between ordinary parents and God the Father. Moreover, who could imagine a human society, without mother and fathers caring for their children, sisters caring for their brothers, and vice versa, friends caring for one another? The question coming from the Jesus tradition to us today, is whether we can have a sustainable and flourishing society, without also caring for strangers - those who are perceived by Jesus and his followers as neighbours, that is, 'proximates'?

From this perspective Jesus, the brother of men and women, does not only have an extended mind, as I argued above. He also appeals to the sense of deep sociality that is the wool and wharf of human societies. Seen from our contemporary evolutionary perspective, this sense of deep sociality has been nourished and cultivated by the deep evolutionary history of our forebears. It is very archaic. And yet it's still with us today.

Deep incarnation is one way of articulating that the person of Jesus, and what he revealed about the human condition, can't be historicised into being just a bygone member of the human race. In a similar way, no individual can be historicised to be just an individual taking care of him- or herself. Being human means experiencing the deep sociality of human existence. A person becomes a person through other persons. The point of Christology is that by conjoining this material world, the Father's eternal Word or Wisdom entered into the matrix of material existence as well as into the social field of human communities.

\section{Acknowledgements}

The author's participation in the conference of the South African Science and Religion Forum (SASRF) of the Research Institute for Theology and Religion held at the University of South Africa, Pretoria 16-18 September 2015, was sponsored by the National Research Foundation of South Africa, facilitated by Prof. Daniel Veldsman.

\section{Competing interests}

The author declares that he has no financial or personal relationships which may have inappropriately influenced them in writing this article.

\section{References}

Balcomb, A.O., 2004, 'Human identity and an African world-view: Some interactions with science and philosophy', in C.W. du Toit (ed.), The integrity of the human person in an African context: Perspectives from science and religion, pp. 59-84, UNISA Research institute for Theology and Religion, Pretoria.

Barrett, J.L., 2004, Why would anyone believe in God?, Altamira Press, Walnut Creek, CA.

Barrett, J.L., 2007, 'Is the spell really broken? Bio-psychological explanations of religion and theistic belief', Theology and Science 5(1), 57-72. http://dx.doi. org/10.1080/14746700601159564 
Barrett, J.L., 2011, Cognitive science, religion, and theology: From human minds to divine minds, Templeton Press, Conshohocken, PA.

Barrett, J.L., 2012, 'The naturalness of religion and the unnaturalness of theology', in D. Evers (ed.), Is religion natural?, pp. 2-23, T\&T Clark, London.

Bellah, R.N., 2011, Religion in human evolution: From the Paleolithic to the axial age, The Belknap Press of Harvard University Press, Cambridge, MA

Bellah, R.N., 2012, 'Religion in human evolutions revisited: Response to commentators', Religion, Brain, and Behavior 2(3), 260-270. http://dx.doi.org/10.1080/215359 9X.2012.712758

Bellah, R.N. \& Joas, H. (eds.), 2012, The axial age and its consequences, The Belknap Press of Harvard University Press, Cambridge, MA

Bering, J., 2011, The belief instinct: The psychology of souls, destiny, and the meaning of life, W.W. Norton, New York, NY.

Boyer, P., 2002, Religion explained: The evolutionary origins of religious thought, Basic Books, New York.

Christensen, L.S., 2015, 'Cultural evolution in the Hebrew Bible: Animal sacrifices, blood sprinkling, sacred texts, and public readings', Jewish Studies 50, 15-35.

Conradie, E.M. \& Du Toit, C.W., 2015, 'Knowledge, values, and beliefs in the South African context since 1948: An overview', Zygon 50(2), 455-479. http://dx.doi. org/10.1111/zygo.12167

Donald, M., 2001, A mind so rare: The evolution of human consciousness, Norton, New York, NY.

Du Toit, C.W. (ed.), 2000, Evolution and creativity: A new dialogue between faith and knowledge, UNISA, Pretoria.

Du Toit, C.W. (ed.), 2010, Homo transcendentalis? Transcendence in science and religion: Interdisciplinary perspectives, Research Institute for Theology and Religion, Pretoria.

Forster, D., 2007, 'Identity in relationship: The ethics of ubuntu as an answer to the impasse of individual consciousness', in C.W. du Toit (ed.), The impact of knowledge systems on human development in Africa, pp. 245-289, UNISA Research institute for Religion and Theology, UNISA.

Gregersen, N.H., 1998, 'A contextual coherence theory for the science-religion dialogue', in N.H. Gregersen \& J.W. van Huysteen (eds.), Rethinking theology and science. Six models for the current dialogue, pp. 181-231, Eerdmans, Grand Rapids, MI.

Gregersen, N.H., 2001, 'The cross of Christ in an evolutionary world', Dialog: A Journa of Theology 40(3), 192-207. http://dx.doi.org/10.1111/0012-2033.00075

Gregersen, N.H., 2003, 'The naturalness of religious imagination and the idea of revelation', Ars Disputandi 3(1), 261-287.

Gregersen, N.H., 2010, 'Deep incarnation: Logos became Flesh', in K. Bloomquist (ed.) Transformative theological perspectives, pp. 167-182, Lutheran University Press, Minneapolis, MN.

Gregersen, N.H., 2012, 'The extended body: The social body of Jesus according to Luke', Dialog: A Journal of Theology 52(3), 235-245. http://dx.doi.org/10.1111/ j.1540-6385.2012.00689.x

Gregersen, N.H., 2013a, 'Deep incarnation and Kenosis: In, with, under, and as. A response to Ted Peters', Dialog: A Journal of Theology 53(3), 251-262.
Gregersen, N.H., 2013b 'Cur deus caro: Jesus and the Cosmos story', Theology and Science 11(4), 270-293. http://dx.doi.org/10.1080/14746700.2013.836891

Gregersen, N.H., 2015a, 'The extended body of Christ: Three dimensions of deep incarnation', in N.H. Gregersen (ed.), Incarnation: On the scope and depths of Christology, pp. 225-252, Fortress Press, Minneapolis, MN.

Gregersen, N.H., 2015b, ‘. Wentzel van Huyssteen: Exploring venues fo interdisciplinary theology', Theology Today 72(2), 141-159. http://dx.doi. org/10.1177/0040573615581547

Johnson, E.A., 2015, 'Jesus and the cosmos: Soundings in deep Christology', in N.H Gregersen (ed.), Incarnation: On the scope and depths of Christology, pp. 133-156, Fortress Press, Minneapolis, MN.

Jørgensen, J., 2008, Jesus Imandars and Christ Bhaktas: Two case studies of interreligious hermeneutics and identity in global Christianity, Peter Lang, Frankfurt am Main.

Mühling, M., 2014, Resonances: Neurobiology, evolution and theology: Evolutionary niche construction, the ecological Brain and Relational-Narrative theology, Vandenhoech \& Ruprecht, Göttingen.

Peirce, C.S., 1998, 'Immortality in the light of Synechism', in The essential peirce. Selected philosophical writings. Volume 2 (1893-1913), pp. 1-3, The Peirce Edition Project, Indiana University Press, Bloomington, IN.

Sayers, D., 1969, Christian Letters to a Post-Christian World, Wm. B. Eerdmans, Grand Rapids, MI.

Scott-Phillips, T.C. \& Laland, K.N., 2014, 'The Niche construction perspective: A critical Appraisal', Evolution 68(3), 1231-1243. http://dx.doi.org/10.1111/evo.12332

Shyrock, A. \& Smail, D.L. (ed.), 2011, 'Introduction', in Shyrock, A. \& Smail, D.L., Deep history: The architecture of past and present, pp. 3-31, California University Press, Berkeley, CA.

Smail, D.L., 2008, On deep history of the brain, University of California Press, Berkeley, CA.

Smith, D.R., 2015, 'A Lutheran theological response to climate change', Theology and Science 13(1), 64-78. http://dx.doi.org/10.1080/14746700.2014.987995

Swidler, A., 2012, 'Where do axial commitments reside? Problems in thinking about the African Case', in R.N. Bellah \& H. Joas (eds.), The axial age and its consequences, pp. 222-247, The Belknap Press of Harvard University Press, Cambridge, MA.

Van Huyssteen, J.W., 2006, Alone in the world. Human uniqueness in science and theology, Eerdmans, Grand Rapids, MI.

Van Huyssteen, J.W., 2011, 'Post-foundationalism and human uniqueness: A reply to responses', Toronto Journal of Theology 27(1), 73-86. http://dx.doi.org/10.3138/ tjt.27.1.73

Veldsman, D.P., 2004, 'Revisiting the implications of contemporary epistemological models for the understanding of religious experience: An Overview', Religion \& Theology 11(3-4), 278-297. http://dx.doi.org/10.1163/157430104X00131

Visala, A., 2011, Naturalism, theism and the cognitive study of religion: Religion explained?, Ashgate, Aldershot, UK.

Watts, F. \& Turner, L.P. (eds.), 2014, Evolution, religion, and cognitive science: Critical and constructive essays, Oxford University Press, Oxford. 